\title{
Osteoporosis, jawbones and periodontal disease
}

\author{
Rosario Guiglia ${ }^{1}$, Olga Di-Fede ${ }^{2}$, Lucio Lo-Russo ${ }^{3}$, Delia Sprini ${ }^{4}$, Giovan-Battista Rini ${ }^{5}$, Giuseppina Campisi ${ }^{6}$
}

${ }^{1}$ DDS, PhD Department of Surgical and Oncological Disciplines, Section Oral Medicine "V. Margiotta", University of Palermo, Via del Vespro 129, 90127 Palermo, Italy

${ }^{2}$ DDS, PhD Department of Surgical and Oncological Disciplines, Section Oral Medicine "V. Margiotta”, University of Palermo, Via del Vespro 129, 90127 Palermo, Italy

${ }^{3}$ DDS, PhD Department of Surgical Sciences, University of Foggia, Viale L. Pinto 1,71100 Foggia, Italy

${ }^{4}$ MD, MS Department of Clinical Medicine and Emerging Diseases, University of Palermo, Via del Vespro 143, 90127 Palermo, Italy

${ }^{5}$ MD, MS Department of Clinical Medicine and Emerging Diseases, University of Palermo, Via del Vespro 143, 90127 Palermo, Italy

${ }^{6}$ DDS, MS Department of Surgical and Oncological Disciplines, Section Oral Medicine "V. Margiotta", University of Palermo, Via del Vespro 129, 90127 Palermo, Italy

Correspondence:

Department of Surgical and Oncological Disciplines

Section Oral Medicine "V. Margiotta"

University of Palermo, Via del Vespro 129

90127 Palermo, Italy

campisi@odonto.unipa.it

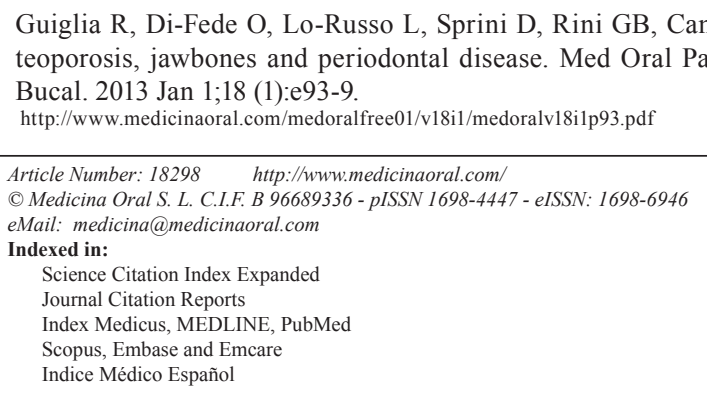

\begin{abstract}
The association between osteoporosis and jawbones remains an argument of debate. Both osteoporosis and periodontal diseases are bone resorptive diseases; it has been hypothesized that osteoporosis could be a risk factor for the progression of periodontal disease and vice versa.

Hypothetical models linking the two conditions exist: in particular, it is supposed that the osteoporosis-related bone mass density reduction may accelerate alveolar bone resorption caused by periodontitis, resulting in a facilitated periodontal bacteria invasion. Invading bacteria, in turn, may alter the normal homeostasis of bone tissue, increasing osteoclastic activity and reducing local and systemic bone density by both direct effects (release of toxins) and/or indirect mechanisms (release of inflammatory mediators). Current evidence provides conflicting results due to potential biases related to study design, samples size and endpoints. The aim of this article is to review and summarize the published literature on the associations between osteoporosis and different oral conditions such as bone loss in the jaws, periodontal diseases, and tooth loss.

Further well-controlled studies are needed to better elucidate the inter-relationship between systemic and oral bone loss and to clarify whether dentists could usefully provide early warning for osteoporosis risk.
\end{abstract}

Key words: Osteoporosis, periodontitis, oral bone loss, tooth loss, edentulism, bone mineral density. 


\section{Introduction}

Osteoporosis (OP) is a systemic skeletal disease characterized by low bone mass and micro architectural deterioration of bone tissue, with a consequent increase in fragility and susceptibility to fracture of bones. In the past, OP was considered a physiological process associated with ageing, but today it is recognized as a multifactorial chronic systemic disease. OP may affect also the jawbones, whose structure may be impaired by other conditions resulting in bone loss. One of these, is periodontitis (PD), a chronic infection-mediated condition modulated by different genetic and environmental factors, characterized, in advanced forms, by loss of the soft tissue attachment to teeth and resorption of alveolar bone . PD is the prototype of a low grade local infection (bacteria of the oral plaque) associated with local (within the periodontal tissues) immune-inflammatory response causing periodontal tissue damages/destruction and a mild individual systemic inflammatory response contributing to the global inflammatory burden and to its related dangerous effects. PD is very prevalent in the general population in the same age range affected by OP. In fact, moderate and advanced periodontitis affects, respectively, approximately $30 \%$ and $10 \%$ of the adult populations of United States. Deep periodontal pockets (the clinical sign of periodontal attachment loss) are present in $2-18 \%$ of adults in western countries and at higher prevalence in developing countries (1) . It might be expected that the alveolar bone destruction seen in periodontitis could be magnified in the presence of generalized skeletal disturbances such as OP. Nonetheless, it is increasingly becoming evident that PD may have several systemic implications (e.g. increased risk for cardiovascular disease), and hypothetical models exist linking OP and PD (1). It is well known that several systemic and local factors may modulate the loss of bone mass and that some of them, as well as many risk factors (Table 1), may be shared between the two conditions.

\section{Material and Methods}

The authors performed a literature review in MEDLINE/ PubMed and Cochrane Oral Health Group's Trial Register by the main key words related (osteoporosis AND periodontitis, osteoporosis AND oral bone loss, osteoporosis AND tooth loss, osteoporosis AND edentulism, osteoporosis AND bone mineral density). In this paper we are going to review further evidence regarding the potential correlation between $\mathrm{OP}$ and $\mathrm{PD}$.

\section{Results}

-Osteoporosis and The Jawbones

OP can affect several skeletal sites including jawbones. Nonetheless, jawbones have some peculiar features related to the type of ossification and the high turnover in- duced by masticator mechanical stresses. Morphological studies have shown that the cortical bone porosity of the upper jaw increases with age; in addition, a considerable variation of the thickness and cortical porosity exists in different areas of the mandible (area of incisors, premolars and molars) in relation to sex, with significantly higher values in males than females. The body of the mandible and the posterior alveolar processes, consisting predominantly of cortical bone, are very similar to the diaphysis of long bones, while in the anterior alveolar processes of the mandible and in the alveolar processes of the jaw, bone architecture is mostly trabecular. According to some authors the rate of bone turnover at the level of alveolar processes would be greater than in long bones, so the loss of bone mass could manifest earlier at the alveolus than at other skeletal segments, thus, representing an early indicator of OP. These observations are consistent with those described by von Wowern et al. (2) who proposed that the mandible suffers from continuous modifications of bone mineral content (BMC) and bone mineral density (BMD) with ageing and in relation to sex. In fact, in older people the mandibular BMC increases, albeit slightly, in males, while it decreases in females (3). This is explained by the presence in elderly males of a compensatory mechanism by which the inner cortical bone is thicker in order to maintain the stability of the atrophic mandibular body, with a reduction of the trabecular bone area. This mechanism does not seem to exist in postmenopausal women, because of OP and/or other such as hormonal and genetic systemic factors.

In addition, whenever teeth are lost the resorption of alveolar residual ridges progressively occurs whether the subject remains edentulous or is rehabilitated with removable prostheses. It has been also found that in patients with osteopenia or OP the porosity observed in the jaws (atrophy from disuse) increases, and that the improvement in chewing produced by prosthetic rehabilitation reduces the amount of bone resorption.

The correlation between changes in systemic BMD and the jawbones, has been assessed by Dual Photon Absorptiometry (DPA) Dual Energy X-ray Absorptiometry (DEXA) and Quantitative Computed Tomography (QCT) (4-5), suitably modified to determine the in vivo BMC. Recently, in some clinical studies the traditional techniques of panoramic radiograph of dental arches or intra-oral (periapical or bitewing) radiograms have been used to assess bone density of the jaws. Most studies showed that these radiographic investigations, used on a routine basis by dentists, have the potential to raise suspicion for OP (Table 2). The relevance of these findings for both early diagnosis of OP is straightforward and underlines the need, for both physicians and dentists, to familiarize with them.

-Periodontitis and Osteoporosis

$\mathrm{PD}$ is a complex disease entity with a multifactorial eti- 
Table 1. Risk factors for osteoporosis (OP) and periodontal disease (PD).

$$
\text { RISK FACTOR S FOR OP }
$$

\section{SYSTEMICS}

- Female gender

- Low body weight / stature / very thin body

- Premature menopause ( $<45$ years)

- Extended periods of amenorrhea

- Lack of estrogen / testosterone

- Previous osteoporotic fracture of the hip, spine or wrist

- Family history of osteoporotic fracture

MALNUTRITION AND MALABSORBIMENT CONDITIONS -Deficient intake of calcium, phosphorus, sodium magnesium,

vitamins D, K, B6, B12

- High consumption of animal protein, coffee, soda, spinach, wheat derivatives

- Anorexia

- Cystic fibrosis

-Inflammatory bowel disease (Chron's disease and ulcerative

colitis)

- Gastrectomy / gastro intestinal bypass

-Celiac

\section{- Aluminum-containing antacids}

- Antiseizure medications (Dilantin or Phenobarbital)

- Aromatase inhibitors (Arimidex, Aromasin and Femara)

- Cancer chemotherapeutic drugs

- Cyclosporine A and FK506 (Tacrolimus)

- Systemic glucocorticoid therapy for $>3$ months with $z$

$5 \mathrm{mg} /$ diecortisone and prednisone

- Gonadotropin releasing hormone (GnRH) (Lupron and Zoladex)

- Lithium

- Medroxyprogesterone acetate for contraception (Depo-Provera)

- Methotrexate

- Proton pump inhibitors (PPIs) (Nexium, Prilosec and Prevacid)

- Selective serotonin reuptake inhibitors (SSRIs) (Lexapro, Prozac

and Zoloft)

- Tamoxifen (premenopausal use)

- Thiazolidenediones (Actos and Avandia)

- Thyroid hormones in excess

- Loop diuretics

- Anticonvulsivant and heparin long term therapy HEREDITARY SKELETAL DISEASES

- Osteogenesis imperfecta

- Rickets

- Hypophosphatasia

\section{ENDOCRINE AND METABOLIC DISEASES}

- Hypogonadism,

- Hyperparathyroidism

- Hyperthyroidism,

- Cushing Syndrome

- Acidosis

- Gaucher's Disease

MARROW DISEASES

- Multiple myeloma

- Lymphoma / leukemia

- Mastocytosis

- Thalassemia

\section{OTHER MEDICAL CONDITIONS THAT CAN LEAD TO} OSTEOPOROSIS

- Chronic renal insufficiency

- Hypercalciuria

- Hepatic Disease

- Systemic Lupus Erythematosus

- Breast cancer

- Emphysema

- Female athlete triad

- Idiopathic scoliosis

- Kidney disease

- Multiple sclerosis

- Organ transplants

- Parkinson's disease

- Post-polio syndrome

- Prostate cancer

- Rheumatoid arthritis

- Severe liver disease (including biliary cirrhosis)

- Thyrotoxicosis

- Depression

- Prolungate immobility (trauma of spinal cord, stroke, muscular dystrophy, ankylosing spondylitis)

OTHER FACTORS

- Inactive lifestyle

- Physical inactivity

\section{COMMON RISK FACTORS}

SYSTEMICS, NOT CHANGED - Ageing

- Race

- Ethnicity

- Genetic predisposition

BEHAVIORAL AND ENVIRONMENTAL - Smoke

- Abuse of alcohol (ingestion of more than $2 / 3$ units of alcohol per day)
. - Socioeconomic status

$$
\begin{aligned}
& \text { ACQUIRED IMMUNODEFICIENCY } \\
& \text { (AIDS / HIV) }
\end{aligned}
$$

ENDOCRINE AND METABOLIC DISEASES

- Insulin-dependent diabetes mellitus DRUGS - Antiepyleptics (phenytoin, fenobarbital) - Cyclosporin
RISK FACTORS FOR PD

\section{- Down syndrom}

SYNDROMES AND HEREDITARY DISEASES WITH ALTERATION OF CONNECTIVE TISSUE

- Ehlers-Danlos syndrome

- Papillon-Lefevre syndrome

SYNDROMES AND HEREDITARY DISEASES WITH PHAGOCYTIC DISFUNCTION

- Quantities disorders or neutropenia

- Congenital neutropenia (Kostmann syndrome)

- Chronic benign neutropenia (familial)

- Cyclic neutropenia

- Felty Syndrome

- Functional disorders of adhesion

- Leukocyte adhesion deficiency

- Functional disorders of chemotaxis

Hypergammaglobulinemia syndrome or Job's syndrome

- Chediak-Higashi syndrome

- Lazy leukocyte syndrome

- Disorders of phagocytosis and the mechanisms microbicides

- Deficiency of myeloperoxidase

- Chronic granulomatous disease

- Deficit of specific granules

DISVITAMINOSI

$$
\text { DRUGS }
$$

Calcium antagonists,

- Oral contraceptives, antiinflammatory drugs

- Protease inhibitors (saquinavir, ritonavir)

$$
\text { STRESS }
$$

HORMONE VARTATIONS

- Puberty, menstruation, pregnancy, menopause

OSTEOPOROSIS and OSTEOPENIA

RADIOTHERAPY

BEHAYTORAL AND FNITRONMENTAL

Bacterial plaque and poor oral hygiene

MICROBIOLOGICAL

Actinobacillus actinomycetemcomitans

- Bacteroides forsythus

- Porphyromonas gingivalis

- Virus

Risk factors tooth related (mucogingival anomalies, presence of iatrogenic factors)

- Occlusal trauma 
Table 2. Assessment of oral BMD by means oral radiographic techniques.

\begin{tabular}{|c|c|c|c|c|}
\hline Authors & Methodical & Index of OP & Patients number & Correlation \\
\hline Klemetti et al 1994 (10) & $\begin{array}{c}\text { BMD of cortical mandible by means } \\
\text { DPR }\end{array}$ & $\begin{array}{l}\text { BMD of spine and } \\
\text { femur }\end{array}$ & $\begin{array}{l}227 \text { postmenopausal } \\
\text { women }\end{array}$ & + \\
\hline $\begin{array}{c}\text { Taguchi et al } \\
1995(11)\end{array}$ & N. of tooth, MCW by means DPR & - & 170 women e 99 men & + \\
\hline Jonasson et al 2001(12) & MABM by means periapical $\mathrm{Rx}$ & BMD forearm & 80 women & + \\
\hline $\begin{array}{l}\text { Bozic and Ihan Hren } 2006 \\
\text { (13) }\end{array}$ & DPR & BMD & $\begin{array}{c}36 \text { women with OP } \\
\text { vs } 20 \text { without OP }\end{array}$ & + \\
\hline Taguchi et al 2006 (14) & DPR & BMD & 836 women & + \\
\hline Karayianni et al 2007 (15) & MCW by means DPR & $\mathrm{BMD}$ & 653 women & + \\
\hline Taguchi et al 2007 (16) & Erosion of cortical mandible & $\begin{array}{l}\text { BMD of spine and } \\
\text { femur }\end{array}$ & 455 women & + \\
\hline Devlin et al 2007 (17) & MCW by means DPR & $\begin{array}{l}\text { BMD of spine and } \\
\text { femur }\end{array}$ & $\begin{array}{l}653 \text { postmenopausal } \\
\text { women }\end{array}$ & + \\
\hline Vlasiadis et al. 2007 (18) & $\begin{array}{l}\text { N. of tooth loos, MCW, PMI, MIC } \\
\text { grade by means DPR }\end{array}$ & BMD of spine & $\begin{array}{l}133 \text { postmenopausal } \\
\text { women }\end{array}$ & + \\
\hline Vlasiadis et al. 2008 (19) & $\begin{array}{l}\text { N. of tooth loos, MCW, Metacarpal } \\
\text { Index, MIC grade by means DPR }\end{array}$ & BMD of spine & $\begin{array}{l}141 \text { postmenopausal } \\
\text { women }\end{array}$ & + \\
\hline $\begin{array}{l}\text { Celenk and Celenk } 2008 \\
\text { (20) }\end{array}$ & BMD by means $\mathrm{CT}$ & $\begin{array}{l}\text { Bone density of } \\
\text { cervical vertebrae }\end{array}$ & $\begin{array}{l}114 \text { patients ( } 46 \\
\text { women, } 68 \text { men) }\end{array}$ & N.E \\
\hline
\end{tabular}

$\mathrm{BMD}=$ Bone Mineral Density; CI = Height of Mandibular Inferior Cortex; CT = Computerized Tomography; DPR = Dental Panoramic Radiograph; MABM = Mandibular Alveolar Bone Mass; MCI = Mandibular Cortex Index; MCW = Mandibular Cortical Width; MIC grade $=$ Morphologic classification of inferior cortical mandibular; N.E. $=$ Not Estimable OP $=$ Osteoporosis; PMI $=$ Panoramic Mandibular Index.

ology in which the inflammatory response of the periodontal tissue to bacterial infection ends up with periodontal ligament detachment from the cement, formation of periodontal pockets, alveolar bone resorption, gingival recession, tooth mobility/migration.

Periodontitis is the major cause of alveolar bone resorption and tooth attachment loss resulting in tooth loss and, consequently, additional bone resorption. It is influenced by environmental factors as well as by genetic factors; thus, periodontal diagnosis requires oral/periodontal and assessment that's to say: 1) patient's medical and dental histories; 2) presence of clinical signs of inflammation of gingival tissues, including bleeding on probing; 3) probing depths; 4); extent and pattern of attachment loss and bone defects 5) presence of various signs and symptoms, including pain, tooth mobility and amount of the observable plaque and calculus (6-7). Obtaining these data needs a thorough clinical and radiographic examination of both intraoral and extra oral structures (8).

The first reports on the possible association between systemic osteoporotic bone loss and local oral bone loss were released back in the '60s by Groen et al. (9) who suggested a possible correlation between the two conditions in patients presenting with both PD and BMD reduction at the forearm and at the spine. Since then, several studies have suggested a possible correlation between loss of systemic bone mass (osteopenia/osteoporosis) and loss of alveolar bone; the latter, however, has been addressed considering the following different series of parameters, many of which are only surrogate measures of PD:

a) clinical attachment level (CAL), depth of the periodontal pocket (PPD);

b) alveolar crest height $(\mathrm{ACH})$ or height of the residual alveolar bone $(\mathrm{ABH})$

c) tooth loss (TL).

The most significant published works for each of them are detailed (Tables 3,4).

\section{Discussion}

OP may affect jawbones and the resulting modifications visible at the routine radiological examination (i.e. dental panoramic radiograph) may be useful for OP early diagnosis. In addition, these modifications might potentially speed up periodontal tissues breakdown caused by PD (2). Under this point of view, although several reports on an epidemiologic basis, support a potential association between PD and OP, the comprehensive analysis of the reported data provides conflicting results; however, it should be noted that reported studies have a wide variation in terms parameters used for assessing both $\mathrm{OP}$ and $\mathrm{PD}$, thus a reliable comparison is somewhat problematic, and, in addition, their design (most of them are cross-sectional, uncontrolled and with small sample size restricted to postmenopausal women) is not adequate to draw robust conclusions (3-4). 
Table 3. Studies on the association between indexes of OP and CAL/PPD.

\begin{tabular}{|c|c|c|c|c|}
\hline Authors & Oral Index & Index of OP & $\begin{array}{l}\text { Study } \\
\text { design }\end{array}$ & Correlation \\
\hline Groen et al. $1968(9)$ & CAL & OP by means rx & $\mathrm{NC}$ & + \\
\hline Phillips and Ashley 1973(21) & PPD & Metacarpal Index & $\mathrm{CSS}$ & + \\
\hline Ward and Manson 1973 (22) & PPD & Metacarpal Index & CSS & - \\
\hline Kribbs et al. $1983(23)$ & PPD & Forearm BMD & CSS & - \\
\hline Kribbs et al. $1990(24)$ & PPD & BMD in health women & CSS & - \\
\hline Kribbs $1990(25)$ & CAL, PPD & OP yes/no & $\mathrm{CSS}$ & - \\
\hline Von Wovern et al. 1992 (26) & CAL & BMC & $\mathrm{P}$ & - \\
\hline Elders et al. $1992(27)$ & PPD & BMD of spine, MCT & CSS & - \\
\hline Mohammad et al. $1996(28)$ & CAL & BMD of spine & CSS & + \\
\hline Von Wovern et al. $1996(29)$ & CAL & $\mathrm{BMC}$ & CSS & - \\
\hline Hildebolt et al 1997 (30) & CAL & BMD of spine and femur & $\mathrm{CSS}$ & - \\
\hline Mohammad et al 1997 (31) & $\mathrm{CAL}$ & BMD of spine & $\mathrm{CSS}$ & + \\
\hline Weyant et al 1999 (7) & CAL & $\begin{array}{l}\text { BMD of spine, femur and wrist in } \\
\text { postmenopausal women }\end{array}$ & CSS & - \\
\hline Payne et al 2000 (32) & CAL & $\begin{array}{l}\text { BMD of spine in postmenopausal } \\
\text { women }\end{array}$ & $\mathrm{P}$ & + \\
\hline Ronderos et al 2000 (33) & CAL & BMD in men and women & $\mathrm{CSS}$ & + \\
\hline Tezal et al 2000 & CAL & $\begin{array}{l}\text { BMD of spine, femur and wrist in } \\
\text { postmenopausal women }\end{array}$ & CSS & + \\
\hline Pilgram et al 2002 (35) & CAL & BMD of femur and column & CSS & - \\
\hline Yoshihara et al 2004 (36) & PAL & BMD in men and women & LS & + \\
\hline Famili et al 2005 & CAL & BMD of femur & - & - \\
\hline Brennan et al 2007 (38) & CAL & $\begin{array}{l}\text { BMD of spine, femur and forearm } \\
\text { in postmenopausal women }\end{array}$ & CSS & + \\
\hline Phipps et al 2007 (39) & CAL, PPD & BMD of spine and femur in men & LS & - \\
\hline $\begin{array}{l}\text { Hattatoglu-Sonmez et al } \\
2008 \text { (40) }\end{array}$ & CAL, PPD & $\begin{array}{l}\text { BMD spine and femur in pre and } \\
\text { postmenopausal women }\end{array}$ & CSS & - \\
\hline
\end{tabular}

BMD = Bone Mineral Density; CAL = Clinic Attachment Level; CSS = Cross Sectional Study; LS = Longitudinal Study; $\mathrm{MCT}=$ Metacarpal Cortical Thickness; $\mathrm{NC}=$ No Controlled Study; $\mathrm{OP}=$ Osteoporosis; $\mathrm{P}=$ Prospective Study; $\mathrm{PAL}=\mathrm{Probing}$ Attachment Level; PPD = Periodontal Pocket Depth; RX = x rays.

Table 4. Studies on the association between BMD and ACH/ABH.

\begin{tabular}{|c|c|c|c|c|}
\hline Authors & Oral Index & Index of OP & $\begin{array}{l}\text { Study } \\
\text { design }\end{array}$ & Correlation \\
\hline $\begin{array}{l}\text { Ward and Manson } 1973 \\
\text { (23) }\end{array}$ & $\mathrm{ABL}$ & Metacarpal Index & CSS & N.E. \\
\hline Humphries et al 1989 (41) & Resorption of residual ridge & Fracture, sex, age & CSS & + \\
\hline Ortman et al 1989 (42) & $\begin{array}{l}\text { Resorption of residual ridge } \\
\text { by means DPR }\end{array}$ & Sex, age & CSS & + \\
\hline Elders et al 1992 (27) & $\mathrm{ABH}$ by means bitewing & $\mathrm{BMD}$ of spine, $\mathrm{MCT}$ & CSS & - \\
\hline Hirai et al 1993 (43) & $\begin{array}{l}\text { Resorption of residual ridge } \\
\text { by means DPR }\end{array}$ & OP yes /no & CSS & + \\
\hline $\begin{array}{c}\text { Wactawski-Wende et al } \\
1996(44)\end{array}$ & $\mathrm{ACH}$ & $\mathrm{BMD}$ of spine and femur & CSS & + \\
\hline Payne et al 1999 (45) & $\mathrm{ABH}$ by means bite-wing & BMD of spine & LS & + \\
\hline Payne et al 2000 (32) & $\mathrm{ACH}$ by means bite-wing & BMD of spine and alveolar bone & $P$ & + \\
\hline Hildebolt et al 2000 (46) & $\begin{array}{c}\text { Distance between CEJ-AC } \\
\text { measured by means bite-wing }\end{array}$ & BMD of spine and femur & CSS & + \\
\hline Pilgram et al 2000 (47) & $\begin{array}{l}\text { ABH by means bite-wing, PPD, } \\
\text { gingival recession }\end{array}$ & Postmenopausal women in HRT & CSS & + \\
\hline Tezal et al 2000 (34) & $\begin{array}{l}\mathrm{ABL}, \mathrm{ACH}, \text { and CAL by means } \\
\text { periapical and bite-wing rx }\end{array}$ & BMD of spine and femur & CSS & + \\
\hline Hildebolt et al 2002 (48) & ACH by means bite-wing & $\mathrm{BMD}$ of spine and femur & $\mathrm{P}$ & N.E \\
\hline $\begin{array}{c}\text { Wactawaski - Wende Jet al } \\
2005(49)\end{array}$ & $\mathrm{ACH}$ by means periapical $\mathrm{rx}$ & $\begin{array}{l}\text { BMD of spine, femur and forearm } \\
\text { in postmenopausal women }\end{array}$ & CSS & + \\
\hline $\begin{array}{c}\text { Brennan-Calanan et al } 2008 \\
(50)\end{array}$ & $\begin{array}{l}\mathrm{ACH} \text { by means periapical } \mathrm{rx} \text { and } \\
\text { bitewing }\end{array}$ & $\begin{array}{l}\text { BMD spine, femur and total body in } \\
\text { postmenopausal women }\end{array}$ & CSS & - \\
\hline
\end{tabular}

$\mathrm{ABH}=$ Alveolar Bone High; $\mathrm{ABL}=$ Alveolar Bone Loss; $\mathrm{ACH}=$ Alveolar Crestal Height; $\mathrm{BMD}=$ Bone Mineral Density; $\mathrm{CAL}=\mathrm{Clinic} \mathrm{At}-$ tachment Level; CEJ-AC = Cement Enamel Junction -Alveolar Crest; CSS = Cross Sectional Study; DPR = Dental Panoramic Radiograph; HRT $=$ Hormonal Replacement Therapy; LS $=$ Longitudinal Study; MCT = Metacarpal Cortical Thickness; N.E. $=$ Not Estimable; OP = Osteoporosis; $\mathrm{P}=$ prospective study; $\mathrm{PPD}=$ Periodontal Pocket Depth.; $\mathrm{RX}=\mathrm{x}$ rays. 
On the other hand, besides the presence of common risk factors, a possible interplay between OP and PD is also suggested at a pathogenetic level. In fact, a bi-directional interference between PD and OP has been proposed: in particular, the reduced $\mathrm{BMD}$, characterizing $\mathrm{OP}$ and the related alteration of trabecular pattern may lead to a more rapid jawbones resorption caused by PD, resulting in the invasion of periodontal bacteria (6-9). Invading bacteria, in turn, may alter the normal homeostasis of bone tissue, increasing osteoclastic activity and reducing local and systemic bone density by both direct effects (release of toxins) and/or indirect mechanisms (release of inflammatory mediators; in particular, interleukin-1 and interleukin-6) .

Thus, a relationship between OP and PD might be probable, but further prospective and sensitive studies are required in order to provide definitive evidence.

By now, available data underline the primary importance of dentists in the early diagnosis of OP, because of the opportunity to assess the health of the entire skeleton of the patient through dental radiography. This is of considerable clinical interest, considering that such dental radiological investigations are routinely performed for diagnosis and treatment of dental and periodontal diseases, which are particularly frequent in the same population affected by OP. This may also provide clues for new preventive strategies and/or early therapeutic approach resulting in a potential reduction of bone resorption and contributing to maintain bone biomechanical characteristics (e.g. architecture, remodelling, quality of matrix collagen and its mineralization).

In fact, the prevention of $\mathrm{OP}$ is the most rational and modern approach to defeat the disease (1), and early diagnosis is one of the foundations of modern medicine; the dentist seems to have an important role not only in monitoring/maintaining the oral and periodontal health and its relationships with systemic health, including OP, but also in drafting diagnostic/ therapeutic paths and participating in counselling for OP in collaboration with general practioners and other specialists.

\section{References}

1. Slots J. Update on general health risk of periodontal diseases. Int Dent J. 2003;53:200-7,

2. von Wowern N, Kollerup G. Symptomatic osteoporosis: a risk factor for residual ridge reduction of the jaws. J Prosthet Dent. 1992;67:656-60.

3. Ulm CW, Solar P, Ulm MR, Matejka M. Sex-related changes in the bone mineral content of atrophic mandibles. Calcif Tissue Int. 1994;54:203-7.

4. Pluskiewicz W, Tarnawska B, Drozdzowska B. Mandibular bone mineral density measured using dual-energy X-ray absorptiometry: relationship to hip bone mineral density and quantitative ultrasound at calcaneus and hand phalanges. Br J Radiol. 2000;73:288-92.

5. Bassi F, Procchio M, Fava C, Schierano G, Preti G. Bone density in human dentate and edentulous mandibles using computed tomography. Clin Oral Implants Res 1999;10:356-61.
6. Bando K, Nitta H, Matsubara M, Ishikawa I. Bone mineral density in periodontally healthy and edentulous postmenopausal women. Ann Periodontol. 1998;3:322-6.

7. Weyant RJ, Pearlstein ME, Churak AP, Forrest K, Famili P, Cauley JA. The association between osteopenia and periodontal attachment loss in older women. J Periodontol. 1999;70:982-91.

8. Kribbs PJ, Chesnut CH, Ott SM, Kilcoyne RF. Relationships between mandibular and skeletal bone in an osteoporotic population. $\mathrm{J}$ Prosthet Dent. 1989;62:703-7.

9. Groen JJ, Menczel J, Shapiro S. Chronic destructive periodontal disease in patients with presenile osteoporosis. J Periodontol. 1968;39:19-23.

10. Klemetti E, Collin HL, Forss H, Markkanen H, Lassila V. Mineral status of skeleton and advanced periodontal disease. J Clin Periodontol. 1994;21:184-8

11. Taguchi A, Tanimoto K, Suei Y, Wada T. Tooth loss and mandibular osteopenia. Oral Surg Oral Med Oral Pathol Oral Radiol Endod. 1995;79:127-32.

12. Jonasson G, Bankvall G, Kiliaridis S. Estimation of skeletal bone mineral density by means of the trabecular pattern of the alveolar bone, its interdental thickness, and the bone mass of the mandible. Oral Surg Oral Med Oral Pathol Oral Radiol Endod. 2001;92:346-52.

13. Bozic M, Ihan Hren N. Osteoporosis and mandibles. Dentomaxillofac Radiol. 2006;35:178-84.

14. Taguchi A, Ohtsuka M, Nakamoto T, Tanimoto K. Screening for osteoporosis by dental panoramic radiographs. Clin Calcium 2006;16:291-97.

15. Karayianni K, Horner K, Mitsea A, Berkas L, Mastoris M, Jacobs R, et al. Accuracy in osteoporosis diagnosis of a combination of mandibular cortical width measurement on dental panoramic radiographs and a clinical risk index (OSIRIS): the OSTEODENT project. Bone. 2007;40:223-9.

16. Taguchi A, Ohtsuka M, Nakamoto T, Naito K, Tsuda M, Kudo Y, et al. Identification of post-menopausal women at risk of osteoporosis by trained general dental practitioners using panoramic radiographs. Dentomaxillofac Radiol. 2007;36:149-54.

17.Devlin H, Karayianni K, Mitsea A, Jacobs R, Lindh C, van der Stelt $\mathrm{P}$, et al. Diagnosing osteoporosis by using dental panoramic radiographs: the OSTEODENT project. Oral Surg Oral Med Oral Pathol Oral Radiol Endod. 2007;104:821-8.

18. Vlasiadis KZ, Skouteris CA, Velegrakis GA, Fragouli I, Neratzoulakis JM, Damilakis J, et al. Mandibular radiomorphometric measurements as indicators of possible osteoporosis in postmenopausal women. Maturitas. 2007;58:226-35.

19. Vlasiadis KZ, Damilakis J, Velegrakis GA, Skouteris CA, Fragouli I, Goumenou A, et al. Relationship between BMD, dental panoramic radiographic findings and biochemical markers of bone turnover in diagnosis of osteoporosis. Maturitas. 2008;59:226-33.

20. Celenk C, Celenk P. Relationship of mandibular and cervical vertebral bone density using computed tomography. Dentomaxillofac Radiol 2008;37:47-51.

21. Phillips HB, Ashley FP. The relationship between periodontal disease and a metacarpal bone index. Br Dent J. 1973;134:237-9.

22. Ward VJ, Manson JD. Alveolar bone loss in periodontal disease and the metacarpal index. J Periodontol. 1973;44:763-9.

23. Kribbs PJ, Smith DE, Chesnut CH. Oral findings in osteoporosis. Part I: Measurement of mandibular bone density. J Prosthet Dent. 1983;50:576-9.

24. Kribbs PJ, Chesnut CH, Ott SM, Kilcoyne RF. Relationships between mandibular and skeletal bone in a population of normal women. J Prosthet Dent. 1990;63:86-9.

25. Kribbs PJ. Comparison of mandibular bone in normal and osteoporotic women. J Prosthet Dent. 1990;63:218-22.

26. von Wowern V, Klausen B, Olgaard K. Steroid-induced mandibular bone loss in relation to marginal periodontal changes. J Clin Periodontol. 1992;19:182-6.

27. Elders PJ, Habets LL, Netelenbos JC, van der Linden LW, van der Stelt PF. The relation between periodontitis and systemic bone 
mass in women between 46 and 55 years of age. J Clin Periodontol. 1992;19:492-6.

28. Mohammad AR, Brunsvold M, Bauer R. The strength of association between systemic postmenopausal osteoporosis and periodontal disease. Int J Prosthodont. 1996;9:479-83.

29. von Wowern N, Klausen B, Hylander E. Bone loss and oral state in patients on home parenteral nutrition. J Parenter Enteral Nutr. 1996;20:105-9.

30. Hildebolt CF, Pilgram TK, Dotson M, Yokoyama-Crothers N, Muckerman J, Hauser J, et al. Attachment loss with postmenopausal age and smoking. J Periodontal Res. 1997;32:619-25.

31. Mohammad AR, Bauer R L, Yeh CK. Spinal bone density and tooth loss in a cohort of postmenopausal women. Int J Prosthodont. 1997;10:381-5.

32. Payne JB, Reinhardt RA, Nummikoski PV, Dunning DG, Patil KD. The association of cigarette smoking with alveolar bone loss in postmenopausal females. J Clin Periodontol. 2000;27:658-64.

33. Ronderos M, Jacobs DR, Himes JH, Pihlstrom BL. Associations of periodontal disease with femoral bone mineral density and estrogen replacement therapy: cross-sectional evaluation of US adults from NHANES III. J Clin Periodontol. 2000;27:778-86.

34. Tezal M, Wactawski-Wende J, Grossi SG, Ho AW, Dunford R, Genco RJ. The relationship between bone mineral density and periodontitis in postmenopausal women. J Periodontol. 2000;71:1492-8. 35. Pilgram TK, Hildebolt CF, Dotson M, Cohen SC, Hauser JF, Kardaris E, et al. Relationships between clinical attachment level and spine and hip bone mineral density: data from healthy postmenopausal women. J Periodontol. 2002;73:298-301.

36. Yoshihara A, Seida Y, Hanada N, Miyazaki H. A longitudinal study of the relationship between periodontal disease and bone mineral density in community-dwelling older adults. J Clin Periodontol. 2004;31:680-4

37. Famili P, Cauley J, Suzuki JB, Weyant R. Longitudinal study of periodontal disease and edentulism with rates of bone loss in older women. J Periodontol. 2005;76:11-5.

38. Brennan RM, Genco RJ, Hovey KM, Trevisan M, WactawskiWende J. Clinical attachment loss, systemic bone density, and subgingival calculus in postmenopausal women. J Periodontol. 2007;78:2104-11.

39 Phipps KR, Chan BK, Madden TE, Geurs NC, Reddy MS, Lewis $\mathrm{CE}$, et al. Longitudinal study of bone density and periodontal disease in men. J Dent Res. 2007;86:1110-4.

40. Hattatoglu-Sonmez E, Ozcakar L, Gokce-Kutsal Y, Karaagaoglu E, Demiralp B, Nazliel-Erverdi H. No alteration in bone mineral density in patients with periodontitis. J Dent Res. 2008;87:79-83.

41. Humphries S, Devlin H, Worthington H. A radiographic investigation into bone resorption of mandibular alveolar bone in elderly edentulous adults. J Dent. 1989;17:94-6.

42. Ortman LF, Hausmann E, Dunford RG. Skeletal osteopenia and residual ridge resorption. J Prosthet Dent. 1989;61:321-5.

43. Hirai T, Ishijima T, Hashikawa Y, Yajima T. Osteoporosis and reduction of residual ridge in edentulous patients. J Prosthet Dent. 1993;69:49-56.

44. Wactawski-Wende J, Grossi SG, Trevisan M, Genco RJ, Tezal M, Dunford RG, et al. The role of osteopenia in oral bone loss and periodontal disease. J Periodontol. 1996;67:1076-84.

45. Payne JB, Reinhardt RA, Nummikoski PV, Patil KD. Longitudinal alveolar bone loss in postmenopausal osteoporotic/osteopenic women. Osteoporos Int. 1999;10:34-40.

46. Hildebolt CF, Pilgram TK, Yokoyama-Crothers N, Vannier MW, Dotson M, Muckerman J, et al. Alveolar bone height and postcranial bone mineral density: negative effects of cigarette smoking and parity. J Periodontol. 2000;71:683-9.

47. Pilgram TK, Hildebolt CF, Yokoyama-Crothers N, Dotson M, Cohen SC, Hauser JF, et al. Relationships between radiographic alveolar bone height and probing attachment level: data from healthy post-menopausal women. J Clin Periodontol. 2000;27:341-6.

48. Hildebolt CF, Pilgram TK, Yokoyama-Crothers N, Vannier MW, Dotson M, Muckerman J, et al. The pattern of alveolar crest height change in healthy postmenopausal women after 3 years of hormone/ estrogen replacement therapy. Periodontol. 2002;73:1279-84.

49. Wactawski-Wende J, Hausmann E, Hovey K, Trevisan M, Grossi $\mathrm{S}$, Genco RJ. The association between osteoporosis and alveolar crestal height in postmenopausal women. J Periodontol. 2005;76:211624.

50. Brennan-Calanan RM, Genco RJ, Wilding GE, Hovey KM, Trevisan $\mathrm{M}$, Wactawski-Wende J. Osteoporosis and oral infection: independent risk factors for oral bone loss. J Dent Res. 2008;87:323-7.

\section{Acknowledgements}

This work is published despite the drastic reduction of public funding for universities and research pursued by the Italian government. 